\title{
SITE-SPECIFIC ERODIBILITY IN CLAYPAN SOILS: DEPENDENCE ON SUBSOIL CHARACTERISTICS
}

\author{
S. Tucker-Kulesza, G. F. Sassenrath, T. Tran, W. Koehn, L. Erickson
}

\begin{abstract}
Soil erosion is a primary factor limiting the productive capacity of many crop production fields and contributing to sediment and nutrient impairments of water bodies. Loss of topsoil is especially critical for areas of limited topsoil depth, such as the claypan area of the central United States. More than a century of conventional agricultural practices have eroded the topsoil and, in places, exposed the unproductive clay layer. This clay layer is impervious, limiting water infiltration and root penetration, and severely restricting agricultural productivity. Previous studies have documented changes in topsoil thickness using apparent electrical conductivity $\left(E C_{a}\right)$. However, that methodology is limited by its shallow depth of measurement within the soil profile, and as such cannot adequately explore factors within the soil profile that potentially contribute to topsoil erosion. In this study, we identified areas of limited topsoil depth using crop yields and $E C_{a}$. Two areas within the production field varying in crop production and $E C_{a}$ were selected for detailed measurements using Electrical Resistivity Tomography. This methodology allowed delineation of soil stratigraphy to a depth of $5.3 \mathrm{~m}$. The erodibility of undisturbed soil samples from the two areas were measured in an Erosion Function Apparatus to obtain the critical shear stress, or the applied stress at which soil begins to erode. Based on resistivity measurement, the highly productive region of the field had a thick $(1.0-2.0 \mathrm{~m})$ soil layer of saturated clayey sand soil over a uniform sandy material, with minimal clay layer. This soil had a critical shear stress of $12 \mathrm{~Pa}$. The extent of historical erosion was evident in the poorly-producing area, as only a thin band of topsoil material remained over a thicker clay layer. The unproductive area with exposed clay layer had a critical shear stress of 128 Pa, indicating it was more resistant to erosion than the highly productive region. The clay layer was found to extend to 1.3-1.5 $\mathrm{m}$ in depth in the soil profile in the poorly producing area. Below this layer was a layer with similar resistivity to the high-producing region. The data reveal the extent of historical erosion within the crop production field and highlight significant variability in measured soil properties within a field of identical production practices. While spatial variations in topsoil have long been considered in developing management practices to improve soil health and productive capacity, our results indicate the importance of identifying variability of subsoil characteristics to address long-term impacts on soil erosion and productivity.
\end{abstract}

Keywords. Soil erosion, Soil electrical conductivity, Claypan soil, Productive capacity, Electrical resistivity tomography.

M anaging agricultural fields to limit sediment loss is critical to maintain the security of water resources and improve the productive capacity of crop fields. Soil losses from nonpoint sources, primarily agricultural operations, impact all aspects of society, contaminating waters of the state and the

\footnotetext{
(c) (i) $\fallingdotseq$ The authors have paid for open access for this article. This Co ${ }_{\mathrm{BY}} \mathrm{NC}$ ND work is licensed under a Creative Commons AttributionNonCommercial-NoDerivatives 4.0 International License https://creative commons.org/licenses/by-nc-nd/4.0/.

Submitted for review in October 2016 as manuscript number NRES 12120; approved for publication by the Natural Resources \& Environmental Systems Community of ASABE in June 2017.

The authors are Stacey E. Tucker-Kulesza, Assistant Professor, Department of Civil Engineering, Kansas State University, Manhattan, Kansas; Gretchen F. Sassenrath, ASABE Member, Associate Professor, Southeast Research and Extension Center and Department of Agronomy, Kansas State University, Parsons, Kansas; Tri Tran, PhD Student, Weston Koehn, PhD Student, Lauren Erickson, Undergraduate Student, Department of Civil Engineering, Kansas State University, Manhattan, Kansas. Corresponding author: Gretchen F. Sassenrath, Southeast Research and Extension Center, 25092 Ness Rd., Parsons, KS 67357; phone: 620-820-6131; e-mail: gsassenrath@ksu.edu.
}

nation. These impaired water resources reduce water quality by fostering toxic algal blooms due to excess nutrients (Grand Lake Watershed Alliance, 2008). Soil sediments congest reservoirs, reducing their capacity for natural flood control and nutrient filtering (Kansas Water Office, 2016). In addition to putting society at risk, the contaminated waters create boundary issues as contaminants from one state impair resources of adjacent states (Kauffman, 2002).

Soil loss is an environmental problem relevant to agriculture (Napoli et al., 2016), as well as ecosystem management (Ito, 2007), biodiversity (Lal, 2003), and infrastructure stability (Briaud, 2006). Soil erosion from claypan soils has long been recognized as a problem, restricting agricultural productivity (Jamison et al., 1968; Sassenrath et al., 2015) and contaminating water bodies (Alarcon and Sassenrath, 2015; in press). Topography is often identified as the critical factor controlling many processes within a field, including water movement over the landscape and erosion processes (Gessler et al., 1995). Understanding how soil properties change within the soil profile is critical to understanding processes exacerbating 
soil loss and limiting the productive capacity of agronomic fields. Surface soil erosion depends on the properties and structure of the soil, the hydraulic loading conditions, and site conditions such as the topography and vegetation (Perovic et al., 2013). Soil erosion is also highly variable within a single watershed (Geng et al., 2015). Surface soil erosion occurs when erosive forces such as the boundary layer shear stress and turbulence from water flow exceed the internal resistive forces of the soil. These resistive forces include gravity, friction, electro-chemical forces, and soil properties.

Claypan soils cover approximately 10 million acres in the United States and are characterized by a highly impermeable layer below the topsoil. This impermeable layer may increase lateral flow and the erosion rate of the upper soil layers (Jamison et al., 1968; Blanco-Canqui et al., 2002). More than a century of agricultural activity in the claypan region has eroded the shallow topsoil layer, restricting the productive capacity of the land and diminishing agronomic returns (Gantzer et al., 1991; Kitchen et al., 2003; Sassenrath et al., 2015). Sediment loss from claypan soils is highly variable, even across regions of identical land management practices (Jung et al., 2005). Researchers have identified that claypan soils have barriers with very low permeability, creating a perched water table that enhances runoff and sediment transport (Jamison et al., 1968; Buckley, 2008). Vegetation increases the erosion resistance at the surface of claypan soils; however, the limited topsoil continues to diminish annually. Knowing measured soil erosion rates and critical shear stress will improve sediment transport models and contribute to the understanding of these soils so remediation solutions can be evaluated.

Soil erodibility, or the susceptibility of soil to erosion, is a key indicator for estimating soil loss (Wang et al., 2013). Soil erodibility is a function of the erosion rate and the applied hydraulic shear stress. The common simplified equation for estimating soil erosion rate, $\grave{\mathrm{o}}_{r}$, is:

$$
\grave{\mathrm{o}}_{r}=k_{d}\left(\tau_{e}-\tau_{c}\right)^{b}
$$

where $k_{d}$ is the soil erodibility coefficient $\left(\mathrm{m}^{3} / \mathrm{N}-\mathrm{s}\right), \tau_{e}$ is the effective hydraulic stress $(\mathrm{Pa})$, and $\tau_{c}$ is the critical shear stress (Pa) (Partheniades, 1965; Hanson, 1990). The exponent $b$ is typically taken as one (Hanson et al., 1999). The soil erodibility coefficient, also called the soil erodibility factor, is considered a soil property and is used in most soil erosion models including the Universal Soil Loss Equation (USLE) (Wischmerier and Smith, 1978), the Revised Universal Soil Loss Equation (RUSLE) (Renard et al., 1991), and the Water Erosion Prediction Model (WEPP) (Flanagan and Nearing 1995). The USLE and RUSLE models estimate the erodibility coefficient based on soil texture, organic content, structural group, and permeability class. The WEPP model utilizes soil texture factors (Alberts et al., 1995) to estimate the erodibility coefficient. As shown in equation 1, the erodibility coefficient alone does not fully describe the erosion rate. The critical shear stress is also a soil property needed to determine soil erosion rates. Although soil texture can be used to estimate the factors in coarse grained soils, Grabowski et al. (2011) note that the erodibility coefficient and critical shear stress of fine grained soils, such as those in this study, are difficult to predict due to the physical, geochemical, and biological relationships that interact dynamically to influence erosion.

Accurate estimation of erodibility parameters is needed to improve soil erosion model predictions; therefore numerous researchers have developed devices to directly measure these parameters. These devices can be divided into four categories based on the applied hydraulic load: rotating apparatus tests, impinging jet erosion tests, sheet flow erosion tests, and pinhole erosion tests. The measured critical shear stress and erodibility coefficient will vary depending on the assumed failure mechanism of the erosion test, therefore it is critical that the selected device model the field application. Our goal was to investigate erosion across the surface of claypan soils, therefore the Erosion Function Apparatus (EFA) was used in this study (Briaud et al., 1999). The EFA is a flume-style test which measures the erosion rate and effective hydraulic stress on the surface of an undisturbed soil sample collected in a thin walled Shelby tube. The EFA simulates sheet flow erosion. More details regarding the EFA test are described in the methodology.

Terrain analysis allows identification of areas of high potential surface erosion. Potential runoff can be calculated using LiDAR-derived digital elevation maps (Moore et al., 1991). The analysis provides information on the paths and relative intensities of flow over the landscape (Momm et al., 2013). This information can be used in conjunction with biological measurements, such as spatial yield maps from crop production fields, to identify areas of historical erosion.

Studies have characterized claypan soils over large scales, mapping surface variability over entire fields. Continuous methods to characterize soils within agricultural fields have been performed by measuring the apparent electrical conductivity, $\mathrm{EC}_{\mathrm{a}}$ (Corwin and Lesch, 2005). Spatial variations in $\mathrm{EC}_{\mathrm{a}}$ are typically attributed to cation exchange capacity, salt, clay and water content in the soil (Kachanoski et al., 1988; Lund and Christy, 1998; Lund et al., 1999; Kitchen et al., 2003; Lerch et al., 2005; Molin and Faulin, 2013) and therefore are valuable tools for mapping variability in soils. Several researchers have compared $\mathrm{EC}_{\mathrm{a}}$ measurements obtained from different near surface geophysical methods or different equipment using these methods (Buchleiter and Farahani, 2002; Doolittle et al., 2001, 2002; Sudduth et al., 2003; Allred et al., 2006). While $\mathrm{EC}_{\mathrm{a}}$ measurements give a more complete picture of withinfield variability than site-specific sampling, it has limitations for studying intrinsic soil properties. $\mathrm{EC}_{\mathrm{a}}$ is the conductivity assuming the Earth is homogeneous. Friedman (2005) notes that because of the shallow depth of measurement, the representative volume of soil in each $\mathrm{EC}_{\mathrm{a}}$ measurement is statistically homogeneous within the spatial resolution of surface $\mathrm{EC}_{\mathrm{a}}$ mappers. Therefore these data are typically not inverted like other geophysical methods that measure greater depths in the subsurface. The commonly implemented measurements of within-field apparent electrical conductivi- 
ty are useful for mapping relative changes in soil characteristics across a field. Comparison of $\mathrm{EC}_{\mathrm{a}}$ to other geophysical measurement methods has limited applicability.

Electrical resistivity tomography (ERT) is a near-surface geophysical method that is becoming increasingly popular in other fields of research beyond geophysics and geology including geotechnical engineering and archaeology. ERT is commonly used to characterize subsurface ground conditions (Griffiths and Barker, 1993; Meads et al., 2003; Lesparre et al., 2016) and for hydrologic mapping (Chandra et al., 2010; Gupta et al. 2015; Whitman and YeboahForson, 2015). ERT has been used for identifying bridge foundations (Arjwech et al., 2013), mapping landfills (Bernstone et al., 2000), and geotechnical characterization prior to infrastructure construction (Hiltunen and Roth, 2003; Snapp et al., 2017). In archaeology, ERT is frequently used to nondestructively identify archaeological structures buried in the subsurface (Gaffney 2008; Papadopoulos et al., 2009). Electrical resistivity is the inverse of electrical conductivity, thus apparent conductivity data $\left(\mathrm{EC}_{\mathrm{a}}\right)$ and apparent resistivity data $\left(\rho_{\mathrm{a}}\right)$ are related. However, ERT surveys measure larger volumes (greater depths) of Earth than $\mathrm{EC}_{\mathrm{a}}$ mappers, therefore ERT data must undergo an inversion process to interpret the subsurface distribution of resistivity rather than directly interpreting measured apparent resistivity data. This limits the comparison of $\mathrm{EC}_{\mathrm{a}}$ and ERT surveys.

The objective of this study was to identify subsurface factors contributing to the observed spatial variability in surface soil properties and productive capacity within a crop field. This research is significant because it contributes to the fundamental understanding of variability of claypan soil erosion and highlights the potential for sediment loss in a managed agricultural field. Field scale $\mathrm{EC}_{\mathrm{a}}$ measurements were used in conjunction with yield maps and terrain analysis to map variability and identify regions for more detailed study. ERT surveys were conducted in regions of high yield, low yield, and perpendicular to the two regions identified from the yield maps and surface $\mathrm{EC}_{\mathrm{a}}$ measurements. Soil samples collected in conjunction with the inverted ERT images showed the variable depth of the claypan layer; traditional surface $\mathrm{EC}_{\mathrm{a}}$ measurements were not able to capture this. The inversion process from ERT measurements to the true resistivity distribution of the subsurface is discussed in this paper. The critical shear stress as related to soil erosion of the soil samples was measured to further characterize the variability of soil properties. The findings presented herein will be utilized to quantify the extent of and delineate possible causes of surface variability in erosion, with an end towards developing and implementing precision conservation methods.

\section{Materials ANd Methods STUDY SITE}

Soils of southeastern Kansas, and particularly the Middle Neosho Watershed, are predominantly Group C and D soils, as classified by the NRCS Soil Hydrologic Group.
Group C soils have a slow infiltration rate when wet due to a fine textured layer that impedes downward movement of water. Group D soils have a very slow rate of infiltration, i.e., high runoff potential. These soils consist chiefly of clays with a high shrink-swell potential. The soils commonly have a claypan, clay layer, or other nearly impervious material near the surface, and have a very slow rate of water transmission.

One 44.5 ha agricultural field that has been in long term conventional crop production was selected for this study. As described by the NRCS Soil Survey (NRCS, 2016), the soil in this field is almost entirely (98.9\%) Wagstaff silty clay loam, one to three percent slope (Oxyaquic Vertic Argiudoll), with very minor inclusions of Zaar silty clay and Wagstaff-Shidler complex at field edges (NRCS, 2016). Wagstaff silty clay loam is classified as prime farmland, hydrologic soil group D, with a restrictive layer underlying the entire field (NRCS, 2016). Wagstaff soils are moderately deep, with a thin loessial topsoil layer overlying a weathered limestone residuum. Typically, the clay pan is located from 0.5 to $0.75 \mathrm{~m}$, with limestone bedrock starting at $0.75 \mathrm{~m}$ (NRCS, 2016). The ten-year annual precipitation at the study location is $114 \mathrm{~cm}$ (Kansas Mesonet, 2016); in the year of study, the total calendar-year precipitation was $132 \mathrm{~cm}$. The ten-year mean annual air temperature in the area of study is $14.5^{\circ} \mathrm{C}$; mean annual air temperature in 2015 was $14.7^{\circ} \mathrm{C}$.

The study site is part of a full-scale commercial farming operation typical of the region. The field has been in continuous crop production, and the usual cropping system produces three crops in two years. Corn is planted in early spring (March-April), harvested in late summer (JulyAugust); winter wheat is planted in early fall (October) and harvested the following spring (June); soybeans are planted in late spring immediately following wheat harvest (June) and harvested in late fall (Oct - Nov). No-till production has been implemented on the field since 2013. Prior to 2013 the field was farmed with conventional tillage. Conventional chemical methods are used for fertilization and to control insects and disease, as needed, using standard protocols for the area (KSU, 2016). Crop yields were measured with an on-board yield monitor on a production-scale combine (AFS Pro700, CaseIH, Inc., Racine, WI). The yield monitor was not calibrated, so reported yields are comparative and not quantitative. Yield data were mapped with SMS Advanced (AgLeader, Ames, Iowa).

Soil samples collected in the upper $1 \mathrm{~m}$ were classified according to the Unified Soil Classification System (USCS). The USCS classifies soils according to particle size via a sieve analysis, ASTM D422 (ASTM, 2007) and plasticity index according to ASTM standard D4318 (ASTM, 2010). The USCS is similar to a textural analysis but fine grained particles are characterized by behavior as opposed to particle size.

\section{TERrain ANALYSIS}

Orthoimagery was downloaded from the U.S. Geological Survey (USGS, 2015) and analyzed using ArcGIS 10.1 
with Spatial Analyst (ESRI, Redlands, Calif.). Highresolution imagery from the USDA National Agricultural Imagery Program (NAIP) was collected between 8 June and 24 July 2012, and between 22 July and 16 September 2014. The NAIP 4-band imagery was used to calculate the NDVI (Mueller et al., 2015). NDVI is commonly used to indicate plant growth based on the near-infrared $(\sim 725 \mathrm{~nm})$ and red $(\sim 600-725 \mathrm{~nm})$ spectral bands.

LiDAR-derived digital elevation maps (DEMs) were downloaded from the Kansas Data Access and Support Center (2016). Terrain analysis was performed using ArcGIS (ESRI, Redlands, Calif.) with the TauDEM toolbox (Tarboton, 2015) to calculate the Specific Contributing Area (SCA; Mueller et al., 2015). Pits were removed from the LiDAR-derived DEM, and D-Infinity flow directions and D-Infinity contributing area calculated in ModelBuilder. Specific Contributing Areas greater than 1,000 and 10,000 were calculated.

\section{Apparent Electrical Conductivity}

Soil apparent electrical conductivity was mapped using a direct contact sensor (Veris Industries, Salina, Kan.) in concert with a GPS system mounted on a tractor. The system uses six $0.43-\mathrm{m}$ diameter disc electrodes that remain in direct contact with the soil surface. Two discs serve as the current source/sink and four measure the resulting voltage potential. The disc spacing controls the depth of penetration of the electrical survey, which were 0.30 and $0.75 \mathrm{~m}$ vertical depth in the soil profile in this study. Sampling was conducted after crop harvest at $9.6 \mathrm{kph}$ in transects every $18.2 \mathrm{~m}$ over the entire field. Soil samples were taken at the same time as Veris readings to determine soil moisture content. Soil moisture contents ranged from $9.4 \%$ to $16.5 \%$ and were found to not correlate to observed changes in $\mathrm{EC}_{\mathrm{a}}$. A total of 8,653 individual $\mathrm{EC}_{\mathrm{a}}$ readings were taken across the entire 44.5 ha field. $\mathrm{EC}_{\mathrm{a}}$ measurements were mapped in SMS Advanced.

\section{ELECTRICAL RESISTIVITY TOMOGRAPHY}

ERT surveys were used to measure the soil profile with depth. Previous researchers have identified that surface $\mathrm{EC}_{\mathrm{a}}$ measurements are correlated with topsoil thickness (Doolittle et al., 1994; Sudduth et al., 2001); however, $\mathrm{EC}_{\mathrm{a}}$ measurements only indicate variability of topsoil thickness and cannot measure deeper in the soil profile. Therefore surface $\mathrm{EC}_{\mathrm{a}}$ measurements were used to identify areas for ERT surveys to image the subsurface with depth. ERT is a near surface geophysical method commonly used for delineating soil stratigraphy (Groves et al., 2011). ERT surveys utilize two electrodes as the current source/sink and at least two electrodes to measure the resulting voltage potential. In a traditional four electrode configuration, the apparent resistivity, $\rho_{\mathrm{a}}$, is

$$
\rho_{a}=\frac{2 \pi V}{I}\left\{\frac{1}{r_{\mathrm{AP}}}-\frac{1}{r_{\mathrm{AQ}}}-\frac{1}{r_{\mathrm{BP}}}+\frac{1}{r_{\mathrm{BQ}}}\right\}^{-1}
$$

where $V$ is the voltage potential difference measured across terminals $\mathrm{P}$ and $\mathrm{Q}, I$ is the input current, and $r$ is the distance between the current sink/source (A and B) and potential electrodes (P and $\mathrm{Q})$. Each apparent resistivity measurement is considered the resistivity that would have been measured if the earth were homogeneous (Everett, 2013), measured in Ohm-meters.

ERT surveys collect apparent resistivity measurements according to equation 2 using multiple electrodes in arbitrary geometric patterns (Daily et al., 2005). The spatial distribution of electrodes used determine the depth of the resistivity measurement into the soil profile. The resulting dataset is a map of the apparent resistivity measurements in the subsurface. At least 84 electrodes were used in each survey and up to eight voltage measurements were collected with each current injection. This intensity of measurement allowed data for each survey to be collected in approximately $1 \mathrm{~h}$. The data acquisition was collected using the dipole-dipole array shown in figure 1. In the dipole-dipole array, the spacing between the current electrodes and between the voltage potential electrodes $(a)$ remains constant for each measurement and these pairs are separated by a factor, $n a$. The dipole-dipole array was used because it collects high resolution laterally and vertically and also has minimal coupling effects (Binley and Kemna, 2005). Coupling effects, which cause noise in the data, are decreased as the distance between the current transmitter and voltage potential receivers are increased. The experimental setup for one ERT survey is shown in figure 2 .

Three ERT surveys were conducted following surface $\mathrm{EC}_{\mathrm{a}}$ mapping using a SuperSting R8 (fig. 2). A uniform $0.31 \mathrm{~m}$ horizontal spacing between the 84 electrodes along the sampling transect was used for the first two surveys, resulting in $25.1 \mathrm{~m}$ long surveys. This survey could image into the soil profile from $0.18 \mathrm{~m}$ to a depth of $5.4 \mathrm{~m}$. The third survey used 112 electrodes spaced $1.52 \mathrm{~m}$ apart horizontally to span the space perpendicular to the first two surveys (fig. 2B). This spacing allowed measurement to a depth of $20 \mathrm{~m}$ in the soil profile. The relative elevation of all electrodes at the soil surface was measured using a Total Station survey. The commercial software EarthImager 2D (AGI, 2007) was used in this study to invert the measured apparent resistivity data to the true resistivity of the subsurface. An Occam-style maximally smooth model inversion was used to solve the nonlinear problem to determine the true resistivity of the subsurface (Constable et al., 1987; Loke and Barker, 1996). The earth was discretized into a two-dimensional finite element mesh with each element assigned a uniform resistivity. The inversion process starts by calculating the apparent resistivity pseudosection from a starting model, taken as the average of all apparent resistivity measurements in this study. The calculated apparent resistivity data are then compared to the

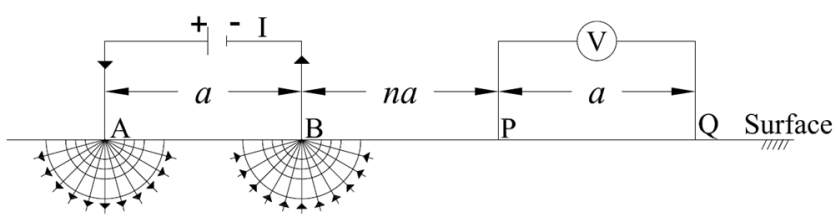

Figure 1. Dipole-dipole array. 


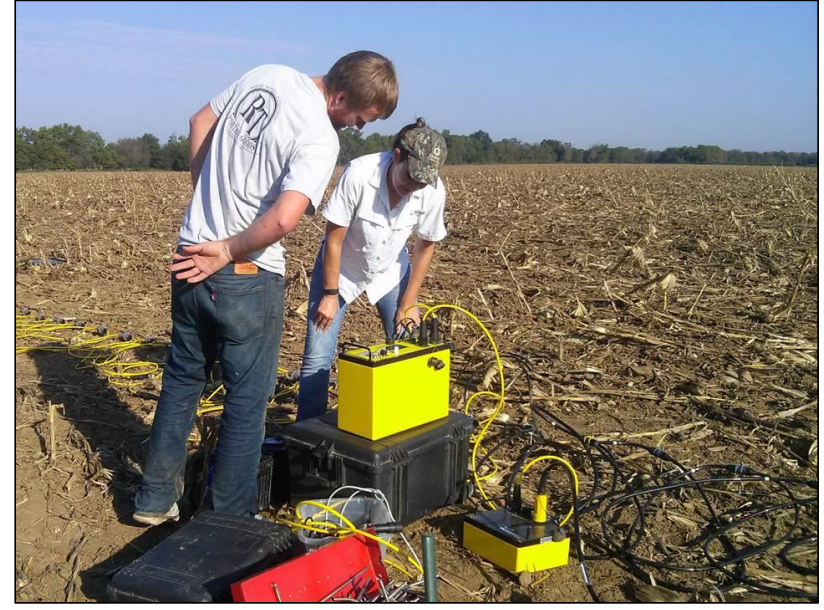

(A)

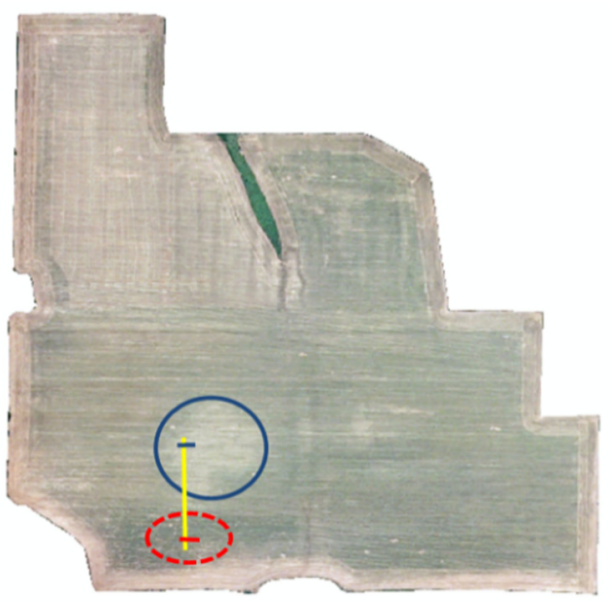

(B)

Figure 2. (A) Experimental setup for one Electrical Resistivity Tomography (ERT) survey. (B) Location of survey transects. The first two surveys used 84 electrodes pushed into the surface at approximately $31 \mathrm{~cm}$ spacing in the low-yielding area (blue line and circle) and highyielding area (red line and oval); 3,478 measurements were collected in each survey. The third survey (yellow line) was perpendicular between the two areas and used 112 electrodes for a total of 6,064 measurements.

measured apparent resistivity. The data misfit of the calculated data is characterized by the RMS errors

$$
R M S=\sqrt{\frac{\sum_{i=1}^{N}\left(\frac{d_{i}^{\text {Pred }}-d_{i}^{\text {Meas }}}{d_{i}^{\text {Meas }}}\right)^{2}}{N}} \times 100 \%
$$

where $d_{i}^{\text {Pred }}$ is the calculated apparent resistivity of each element, $d_{i}{ }^{\text {Meas }}$ is the measured apparent resistivity of each element, and $N$ is the number of measurements. A second measure of the goodness of fit, L2-norm was also used. The L2-norm is calculated by:

$$
L 2-N o r m=\sum_{i=1}^{N}\left(\frac{d_{i}^{\text {Pred }}-d_{i}^{\text {Meas }}}{W_{i}}\right)^{2}
$$

where $W_{i}$ is the data weight and all other variables have previously been defined. The L2-norm depends on the estimate of data weights, or errors. Typically RMS less than $3 \%$ is considered an excellent fit, $3-5 \%$ a good fit, and $6 \%-10 \%$ is acceptable but should be interpreted with caution (Tucker et al., 2015). The objective of the inversion process is to have as few iterations as possible while still meeting the RMS and L2-norm stop criteria. Therefore, the quality of the inversion can be interpreted by noting the number of iterations, the RMS, and the L2-norm (L2 on the inversion image) of the final model.

In a smooth inversion, the objective is to find the solution that fits within a set criterion; less than 5\% RMS and L2-norm less than one in this study. The stop criterion RMS is also the estimated noise in the Occam style inversion. If the estimated noise is appropriate for the measured data, the L2-norm will be less than unity indicating the inversion has converged. The smooth model is a mathematically stable inversion that results in a model with fewer mathematical artifacts. Once the inverse problem is solved, the calculated apparent resistivity model is updated and the data misfit recalculated. The iterative procedure continues until data misfits are below the stop criteria. The final results of the inversions are images of the spatial variations of the true resistivity of the subsurface.

Although two geoelectrical methods were used at the same site, $\mathrm{EC}_{\mathrm{a}}$ measured with the Veris mapper and the apparent resistivity measured for the ERT surveys cannot be directly compared. Gebbers et al. (2009) compared data in the same area collected with various geoelectrical instruments for mapping at the field scale including a multi-electrode system, such as the SuperSting R8 used in this study, and a Veris mapper. They noted that comparison between instruments should only be made when the electrode spacing and signal depth of penetrations are the same. The Veris mapper and SuperSting both assume the apparent measurements occur at the median depth, $\mathrm{z}_{\mathrm{med}}$, or the depth where $50 \%$ of the electrical signal is above and below defined by Edwards (1977). The electrode spacing and median depth for the two systems were different and thus cannot be compared directly; therefore apparent resistivity data from the ERT survey are not shown herein. The $\mathrm{EC}_{\mathrm{a}}$ data were only used in conjunction with the yield mapping to identify areas of variable soil properties. These regions were then studied in more detail with ERT to image the variable depth of the subsoil.

\section{ERosion FunCtion APPARATUS TESTING}

Numerous testing devices have been developed to measure the soil erodibility, or rate of soil erosion. The EFA was developed for measuring the erodibility of undisturbed soil samples for bridge scour predictions (Briaud et al., 1999). Soil samples were collected from the field in $45 \mathrm{~cm}$ long, $7.6 \mathrm{~cm}$ diameter thin-walled Shelby tubes via a direct push method coincident with the ERT surveys. Soil samples were collected from the middle of each of the shorter ERT transects. The EFA (fig. 3) was used to directly measure the erosion rate of the soil samples 


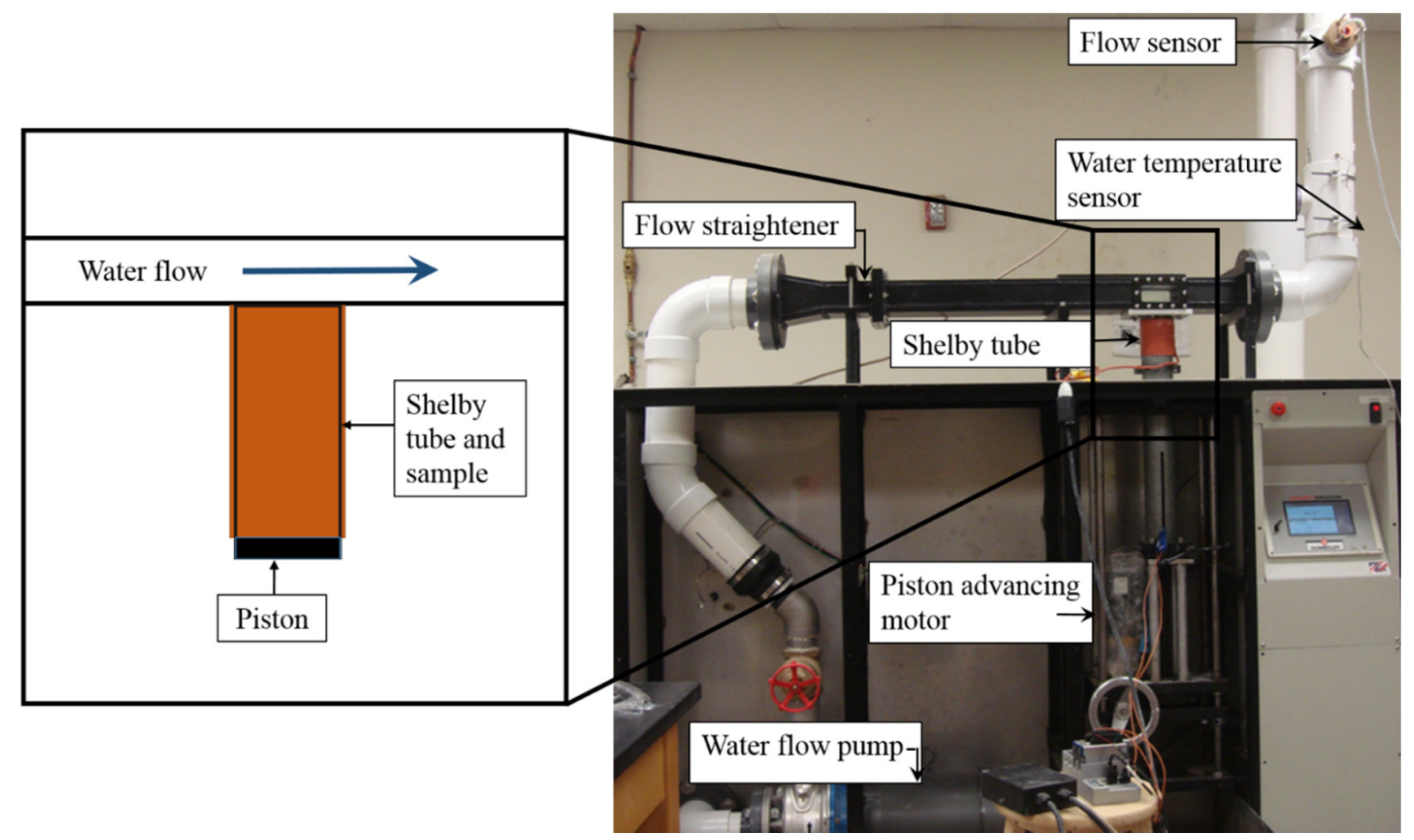

Figure 3. Kansas State University Erosion Function Apparatus (EFA).

to obtain the critical shear stress. The critical shear stress is the applied hydraulic stress at which a soil starts to erode (Bernhardt et al., 2011) and a higher critical shear stress indicates that a soil is more resistant to erosion. The Shelby tube was inserted into an opening in the flume so that the top of the tube was flush with the bottom of the flume. The soil was kept flush with the flume as water flowed over the sample and the amount of soil eroded over a specified period was measured. This process was repeated six times for each sample, increasing the flow of the water for each point.

The distance traveled by the piston during a flow velocity was recorded by the EFA. The erosion rate was determined by measuring the distance traveled by the piston and therefore the amount of soil eroded over a set period of time $(\mathrm{mm} / \mathrm{h})$ for each flow velocity of water. The applied hydraulic shear stress on the surface of the soil was also calculated for each flow velocity. The shear stress on the surface is calculated as:

$$
\tau_{e}=\frac{1}{8} f \rho v^{2}
$$

where $\tau_{e}$ is the shear stress on the surface measured in $\mathrm{N} / \mathrm{m}^{2}(\mathrm{~Pa}), \rho$ is the mass density of water, $v$ is the flow velocity, and $f$ is the friction factor obtained from the Moody Chart using the soil roughness (Moody 1944; Munson et al. 1990; Tran et al., 2017).The roughness of the sample following each flow velocity was measured using a custom digital photogrammetry process to measure the relative elevations across the soil sample (Tran et al., 2017). The arithmetic average roughness, $R_{a}$, is the average of the absolute distances of all vertical lines from the mean line (top of the Shelby tube) such that:

$$
R_{a}=\frac{1}{N} \int|y(x)| d x
$$

where $N$ is the number of measured points and $y(x)$ is the individually measured height (Gadelmawla et al., 2002). In traditional EFA tests the surface roughness is measured by hand with calipers, selecting approximately ten peaks and valleys across the sample that are created from the water flow. Tran et al. (in review) compared the arithmetic average roughness of a 3D printed disk measured with a structured light scanner, calipers, and the custom digital photogrammetry process; the variability between the structured light scanner and photogrammetric method was $0.09 \mathrm{~mm}$ verifying the accuracy of the photogrammetric process. The photogrammetry method removes the operator dependence of measuring soil roughness with hand calipers and does not require the high capital investment of a structured light scanner. Once pictures were taken for the roughness measurements following a flow velocity the soil sample was trimmed flush with the top of the Shelby tube and the process was repeated for the next velocity. The total push distance during the full EFA test was less than 8 $\mathrm{mm}$ for one sample reading and less than $22 \mathrm{~mm}$ for the second; therefore, all velocity measurements were conducted in the same soil horizon. The erosion tests were run until at least two velocities resulted in measureable soil erosion. The erosion rate was plotted versus the corresponding effective hydraulic stress (eq. 5). From this data, the critical shear stress, or the stress at which the soil starts to erode was determined by projecting a best fit line back to zero erosion rate. 


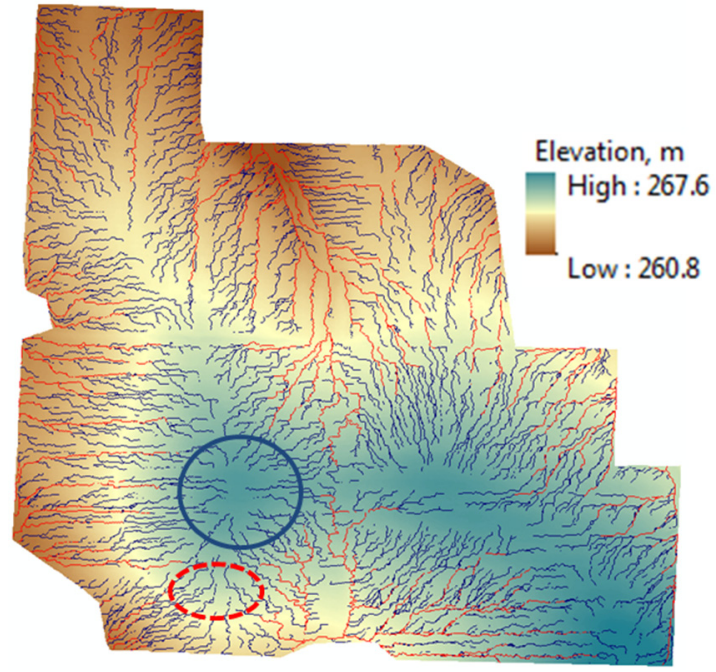

Figure 4. LiDAR-derived digital elevation map of the field of study. TauDEM (Tarboton, 2015) was used to identify areas of highest water outflow from the field. Specific Contributing Area (SCA) above 1000 (blue) and above 10,000 (red) determined using TauDEM.

\section{RESULTS}

\section{TERRAIn ANALYSIS}

The 260-ha section in which the field lies is dissected by Lake Creek and its tributaries. Elevation in the section ranges from a high of $270 \mathrm{~m}$ above sea level to a low of $250 \mathrm{~m}$ at the bottom of the creek. The LiDAR-derived DEM shows a high ridge located through the center of the field, with the highest area in the southern half of the field. Elevation in the field varies $6.8 \mathrm{~m}$ between the high point at 267.6 to $260.8 \mathrm{~m}$ at the field edges (fig. 4).

As shown in figure 4, flow paths through the field originate from the high ridge in the middle of the field and flow towards the field edges. The high point in the middle of the field (blue circle) has no contributing paths, but instead contributes to flow in all compass directions away from this area. The high-yielding area of study to the south of the high point (red dashed oval) is at a lower elevation and receives inflows from higher elevations.

\section{Crop Production}

Although the entire field has been classified as a single soil type (NRCS, 2016), the extent of within-field variability is apparent from changes in soil color in the bare-soil imagery (fig. 5A), collected in late summer 2014 following harvest. Fleming et al. (2004) showed the potential of using changes in soil color to identify variability within crop production fields. The variability of crop growth is even more apparent in the NDVI image, calculated from the 2012 crop canopy image (fig. 5B). A grassed waterway bisects the field towards the north. The waterway is not farmed, though the area surrounding it is farmed. The center of the waterway has high plant coverage

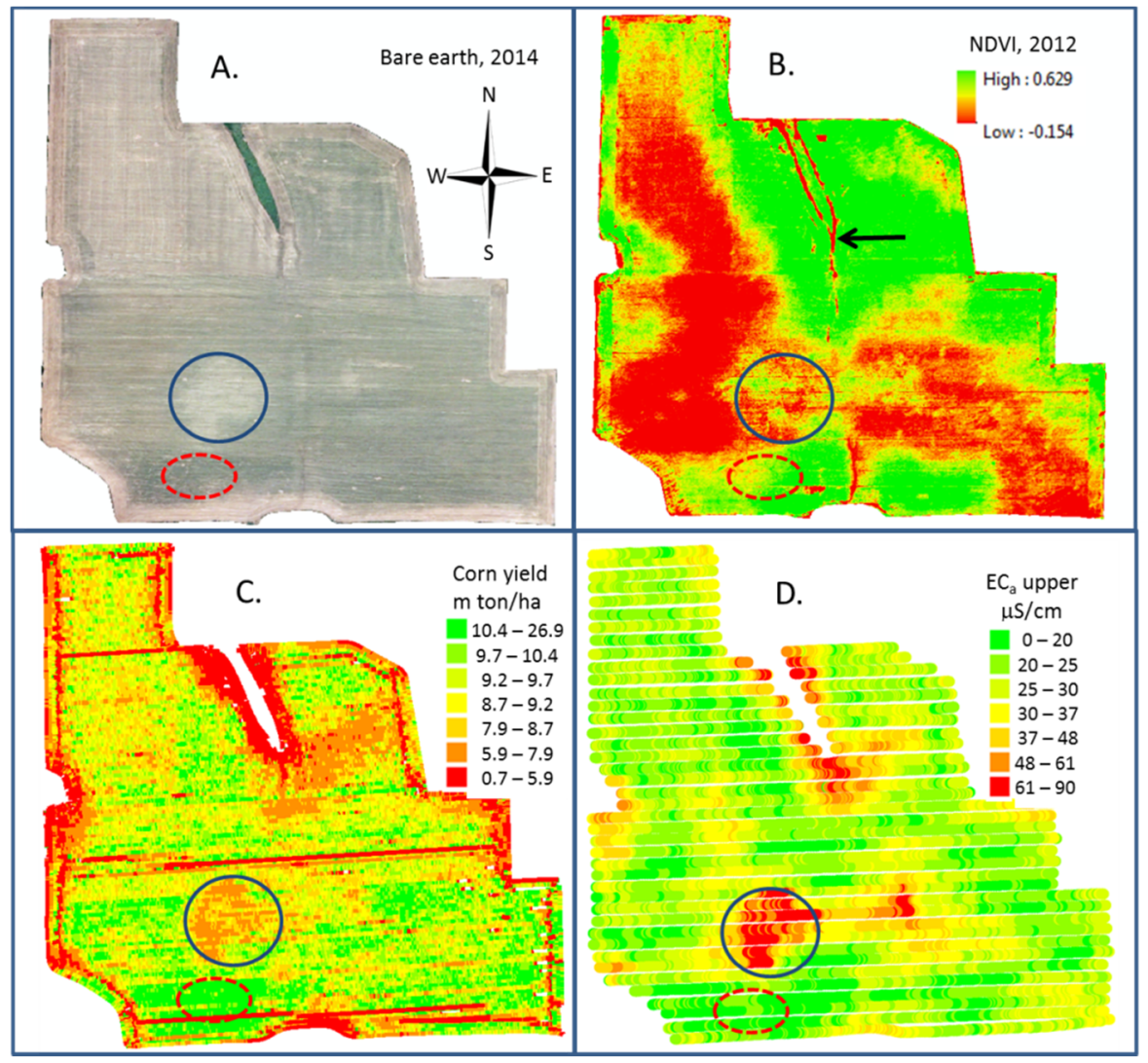

Figure 5. (A) Bare earth NAIP image of field from 2014. (B) NDVI calculated from NAIP imagery from 2012. The grassed waterway is indicated by arrow. (C) Yield map of field from commercial combine. (D) Apparent electrical conductivity of field measured with a Veris EC sensor system. The high-yielding area is highlighted by the southern (red, dashed) oval; the poor-yielding area is highlighted by the northern (blue, solid) circle. 
due to weed growth; the outline of the waterway is seen as the red area surrounding the waterway in the NDVI and the beginning of it is marked with an arrow (fig. 5B). Crops are planted up to this intersection, and on either side of the grassed waterway.

Corn yield showed a response to the variability of the soil within the field (fig. 5C). The yield map highlights poorly performing areas of the field, with yields below $5.9 \mathrm{t} / \mathrm{ha}$. The low-lying area surrounding and to the east of the waterway in the north part of the field has low yield. A second area of low yield is in the center of the field, corresponding to the lighter soil at the high point in the bare-soil image. An exceptionally high-yielding area is directly south of this low-yielding area.

\section{Electrical ConduCtivity}

The measurement shown in figure $5 \mathrm{D}$ is apparent conductivity, $\mathrm{EC}_{\mathrm{a}}$, of the upper soil layer measured at approximately $0.31 \mathrm{~m}$ depth in the soil profile. The resulting data set is the surface spatial distribution of $\mathrm{EC}_{\mathrm{a}}$ which is a function of static and dynamic soil factors including clay content, water content, bulk density, temperature, and salinity (Rhoades et al., 1989). The $\mathrm{EC}_{\mathrm{a}}$ shows high electrical conductivity $(61-90 \mu \mathrm{S} / \mathrm{cm})$ at $0.31 \mathrm{~m}$ depth in low-lying areas in the north part of the field and the high point of the field in the middle of the field (fig. 5D). Variability in $\mathrm{EC}_{\mathrm{a}}$ throughout the field is similar to that observed in crop growth and yield (fig. 5C). The direct contact method is used for measuring surface geoelectrical properties at the field scale and has been used by numerous researchers (Gebbers et al., 2009; Molin and Faulin, 2013; Doolittle and Brevik, 2014). Higher $\mathrm{EC}_{\mathrm{a}}$ has been correlated to higher clay content in clay-pan soils (Kitchen et al., 2005). Soil water content was measured coincident to apparent conductivity measurements and ranged from $9.4 \%$ to $16.5 \%$ at the soil surface; no correlation was observed between $\mathrm{EC}_{\mathrm{a}}$ and soil moisture (data not presented). The pattern of soil $\mathrm{EC}_{\mathrm{a}}$ is similar between the "upper" $(31 \mathrm{~cm})$ and "lower" $(75 \mathrm{~cm})$ Veris readings, hence only the upper readings are reported here.

The substantial variability in soil characteristics within the field was evident from the $\mathrm{EC}_{\mathrm{a}}$ and crop response. To better define the factors contributing to that variability, we examined changes in the soil profile using ERT. Based on soil and crop data and the terrain analysis, two areas within the field were selected for more detailed measurements. The low-yielding, unproductive area in the middle of the field, highlighted by the blue circle, and the high-yielding, productive area to the south of that, highlighted by the red dashed oval in figure 5, were selected for more extensive measurements as described below.

\section{ELECTRICAL RESISTIVITY TOMOGRAPHY}

The ERT measurement of the highly productive area (fig. 2B, red line), shown in figure 6, converged within two iterations with a root mean square (RMS) of $4.20 \%$ and L2 of 0.55 , which are within the stop criteria set for this study and indicate a good fit. Two layers are evident in figure 6; the upper layer had a measured resistivity of 25 to $50 \Omega-\mathrm{m}$ from the surface (El. $266 \mathrm{~m}$ ) to approximately El. $264 \mathrm{~m}$. According to Everett (2013), wet to moist sands have a resistivity between 20 and $200 \Omega-\mathrm{m}$. The soil at the surface was classified as a clayey sand (SC) according to the USCS, further supporting the electrical resistivity interpretation. The average resistivity of the layer was approximately $30 \Omega-\mathrm{m}$, likely towards the lower end of the typical ranges of sand due to the presence of clay. The SC overlies a layer with measured resistivity between 100 and $200 \Omega-\mathrm{m}$ from El $264 \mathrm{~m}$ to the bottom of the measured transect (5.3 $\mathrm{m}$ depth in the soil profile). This layer is comparable to a weathered limestone or sandstone (Sharma, 1997; Everett 2013), which would be commensurate with the NRCS soil classification (2016) of the presence of weathered limestone at approximately $0.75 \mathrm{~m}$ in this soil type. The thin layer of approximately $80 \Omega-\mathrm{m}$ between the two mediums is likely due to smoothing of resistivity at a sharp boundary.

The ERT of the poorly producing area (fig. 2B, blue line) shown in figure 7 converged in three iterations with an RMS of $4.53 \%$ and an L2 of 0.48 , indicating a good estimate of the data noise and model fit. Figure 7 indicates a very low resistivity (or highly conductive) clay layer of 2 to $10 \Omega-\mathrm{m}$ from the surface (El. 266.7 to $267.3 \mathrm{~m}$ ) to $1.5 \mathrm{~m}$ depth in the soil profile. Soil samples collected from this site classified as a low-permeability fat clay $(\mathrm{CH})$ according to the USCS, again supporting the resistivity interpretation. The surface has some soil pockets with relatively higher resistivity measurements that are 13 to $20 \Omega-\mathrm{m}$ at the $21 \mathrm{~m}$ marker. This is a thin layer of remaining topsoil, however the measured resistivity is likely lower than anticipated due to the proximity of the highly conductive claypan. The presence of the clay layer at much shallower depth than typical for this soil demonstrates that extensive erosion has occurred at this site, exposing the clay layer. The clay layer extends to a depth of 1.3 to $1.5 \mathrm{~m}$ in the soil profile. Below this clay layer is a region of higher resistivity, approximately 30 to

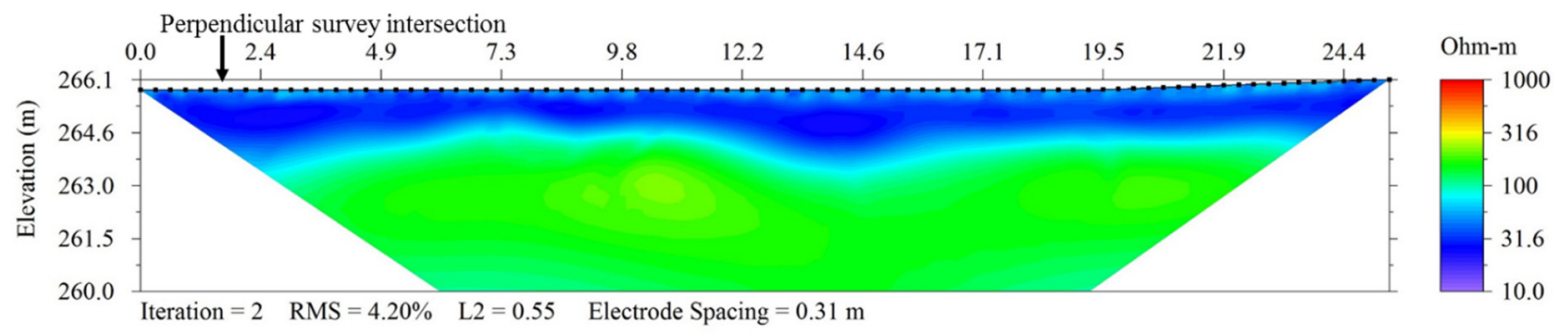

Figure 6. ERT the highly productive area (red line, fig. 2B). The results indicate a saturated clayey sand layer over a weather limestone. 


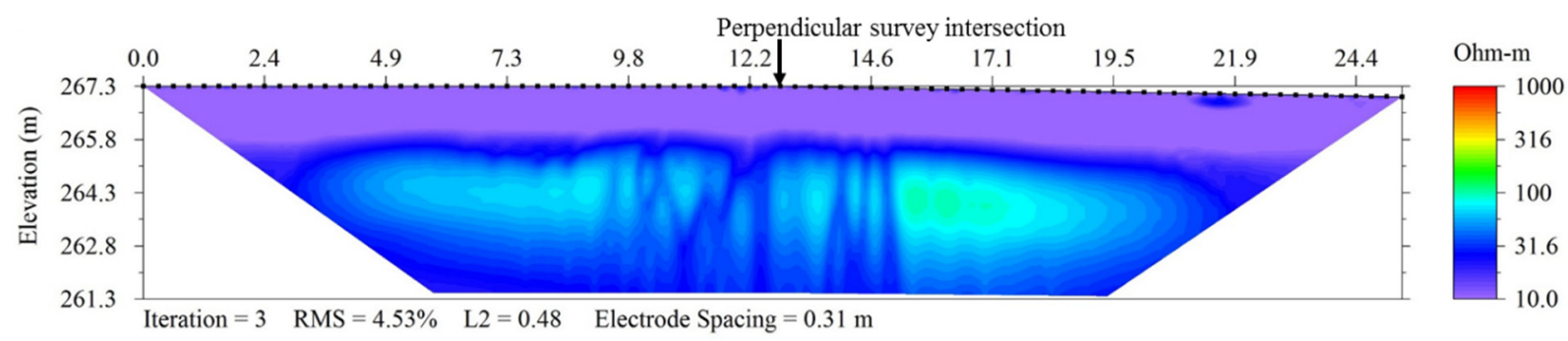

Figure 7. ERT across the unproductive area of the field (blue line, fig. 2B). The low resistivity $(\sim 10 \Omega-m)$ indicates the low permeability and low erodibility of the claypan layer at the surface.

$100 \Omega$-m. The soils below the clay layer had similar resistivity to the soils in figure 6 .

The ERT measurements shown in figure 6 and 7 both have a uniform upper layer to approximately $1.5 \mathrm{~m}$ depth in the soil profile. In the highly productive region (fig. 6) the upper layer is a sandy material (SC) over a weathered limestone. In the low-yielding, unproductive region (fig. 7) the top, impermeable clay layer $(\mathrm{CH})$ overlies a material with similar resistivity to the SC at the surface in figure 6 . Interestingly, the impermeable clay layer, commonly associated with claypan soils, was not evident in the productive region deeper in the profile. Therefore, a third ERT measurement was conducted perpendicular to and spanning between the first two ERT measurements presented in figures 6 and 7 to image the subsoil characteristics between the two regions (fig. 2B, yellow line).

The ERT measurements in figure 8 show that the claypan layer does not shift downward but rather dissipates between the two regions. The two lines on the ERT in figure 8 indicate where the poorly producing region of figure 7 was measured and where the high producing region in figure 6 was measured (both survey transects are perpendicular to the page). The increased spacing between electrodes of the survey in figure 8 allowed a longer survey and greater depth of measurement into the soil profile. Figure 8 was obtained by running two ERT surveys with 56 electrodes and using the last electrode of the first survey as the first electrode of the second survey. The objective was to image the upper $1.5 \mathrm{~m}$ between the highly productive and unproductive regions, however no data were collected directly beneath the overlapping surveys. The combined ERT surveys converged in three iterations to an RMS of $8.72 \%$ and L2 of 0.24 . The higher RMS was anticipated because of the area between the surveys where no data were collected. The higher RMS is still an acceptable fit and L2 less than unity indicates the estimated noise was appropriate for this data set. The two individual surveys were inverted separately and converged to RMS less than 3\% and L2 less than unity, further supporting the quality of the data. The combined data set is shown herein to improve visualization of the dissipating claypan at the surface.

The depth of claypan (soil with resistivity of approximately $10 \Omega-\mathrm{m}$ ) overlying a similar sandy material (30$80 \Omega-\mathrm{m}$ ) is consistent in the unproductive area (left side of fig. 8B). Similarly, the sandy material overlying a higher resistivity material is verified on the right side of the transect in the productive area. A higher resistivity zone is seen, starting at approximately El $261.7 \mathrm{~m}$, across both surveys. This region, approximately 800 to $1000 \Omega$-m, is likely the limestone bedrock.

\section{SoIL ERODIBILITY}

Surface erosion tests were conducted to measure the critical shear stress of the soils from the two sites in figures 6 and 7. The $45 \mathrm{~cm}$ long, $7.6 \mathrm{~cm}$ diameter soil samples were tested at six velocities, from 1 to $6 \mathrm{~m} / \mathrm{s}$. Figure 9 shows the low yield and high yield samples following the $5 \mathrm{~m} / \mathrm{s}$ flow velocity and the resulting measured roughness amplitudes. Each blue line represents the distance above or below the plane of the Shelby tube to calculate the roughness of the sample. Pictures similar to these were taken following each velocity to obtain roughness and calculate the applied shear stress, $\tau_{\mathrm{e}}$ in equations 5 and 6.

The results of the full EFA tests are shown in table 1. There was no measurable erosion of the soil sample collected from the low-yielding, unproductive area in the ERT profile shown in figure 8 until $5 \mathrm{~m} / \mathrm{s}$. Therefore, the

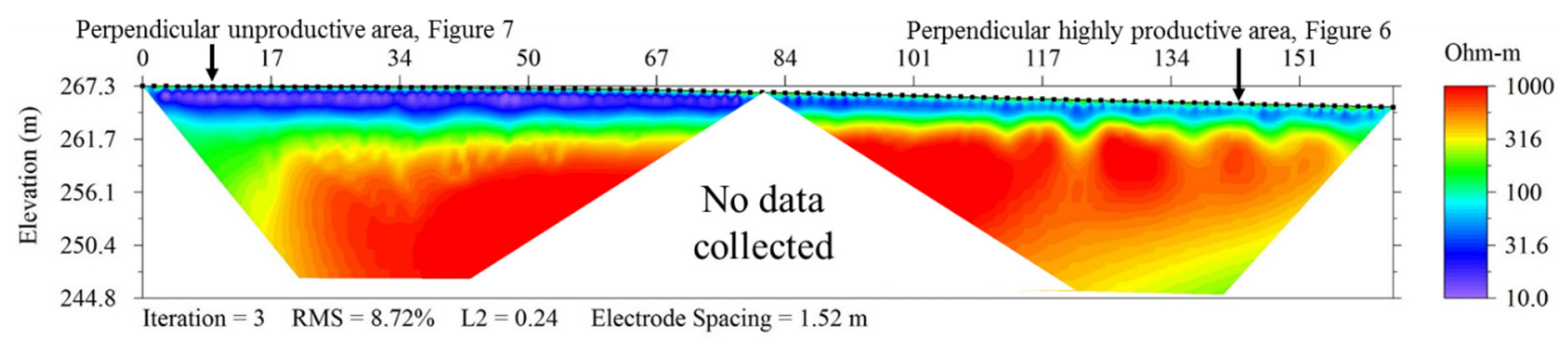

Figure 8. ERT survey taken perpendicular (yellow line, fig. 2B) to the previous two surveys between the unproductive area of the field (blue line, fig. 2B) and the highly productive area (red line, fig. 2B). The approximate depth of the surveys shown in figure 6 and 7 are marked with horizontal lines. Two surveys were arranged so that the last electrode of the first survey was the first electrode of the second at the $84 \mathrm{~m}$ marker. The greater spacing between electrodes in this survey allowed measurement at greater depth into the soil profile. 

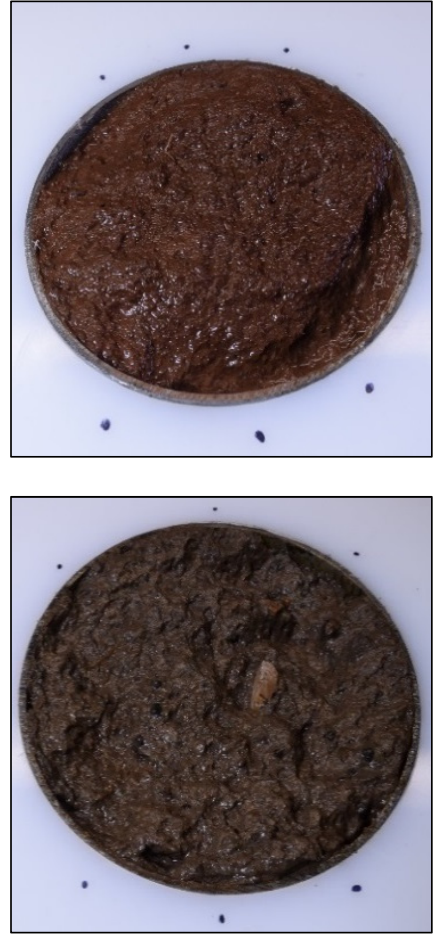
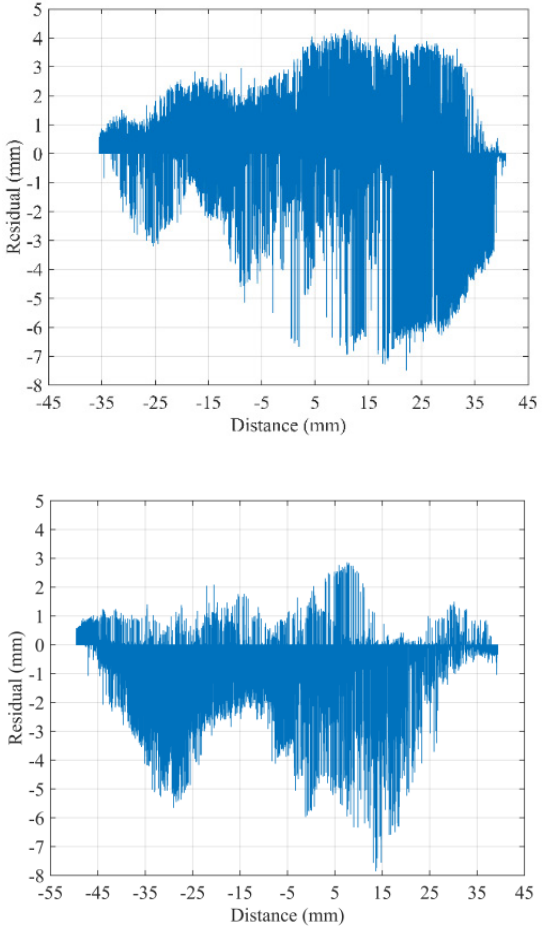

Figure 9. Soil samples following $5 \mathrm{~m} / \mathrm{s}$ flow velocity and resulting roughness measurements calculated with digital photogrammetry. Top images are from the high productive area sample, bottom images are from the low productive area.

unproductive sample was tested at one velocity above $5 \mathrm{~m} / \mathrm{s}$ to get two measures of erosion. The erosion rates and calculated shear stresses are plotted in figure 10. The first data points at $1 \mathrm{~m} / \mathrm{s}$ were not plotted to improve visualization of the critical shear stress for each sample (neither soil eroded at this velocity). Note that the last data point from the sample from the unproductive region was the most measured erosion in the full test, however the erosion rate is not the data of interest; the resulting applied shear stress was the objective of measuring at such high velocities.

As previously stated, a key measurement in soil erodibility is the critical shear stress, or the shear stress at which the soil starts to erode. The critical shear stress for the high yield area was $12 \mathrm{~Pa}$ whereas the critical shear stress for the low-yield area was $128 \mathrm{~Pa}$, indicating the lowyield region is more erosion resistant. This high critical shear stress is likely causing water to flow laterally along the clay surface, increasing water flow to the other regions of the field, including towards the high-yield region. Researchers have established that topsoil is diminishing in the claypan region (Gantzer et al., 1991; Kitchen et al., 1999; Jung et al., 2005; Jiang et al., 2007); increasing flow from one region of the field to another where soils erode more easily is likely exacerbating this process. Furthermore, these data can be used to determine the erodibility coefficient, $k_{d}$, for claypan soils. Knowing the critical shear stress and erodibility coefficient of claypan soils helps to further characterize claypan soils.

\section{CONCLUSIONS}

Previous studies have measured the variability of topsoil depth with $\mathrm{EC}_{\mathrm{a}}$ (Doolittle et al., 1994; Kitchen et al., 2005). While the depth of topsoil is often considered the causative factor for low crop yields, variability in subsoil characteristics are not considered. The ERT surveys measured deeper in the soil profile than traditional surface $\mathrm{EC}_{\mathrm{a}}$ measurements and revealed the extent of spatial variability of subsoil characteristics. Previous surveys indicated a consistent claypan under the entire field (NRCS, 2016). Our results indicate, however, that the clay layer is not present homogeneously throughout the field. While topographic position may indicate topsoil has simply eroded off of the hilltop and been deposited on the lower position within the field, measurement of the subsoil characteristics indicate this process could not account for the diminution of the clay layer in the region of lower

Table 1. Results of EFA testing for the high yield and low yield samples.

\begin{tabular}{|c|c|c|c|c|c|c|c|c|}
\hline \multirow[b]{2}{*}{ Sample } & \multirow[b]{2}{*}{ Measurement } & \multicolumn{6}{|c|}{ Flow Velocity } & \multirow{2}{*}{$\begin{array}{c}\text { Critical Shear } \\
\text { Stress }(\mathrm{Pa})\end{array}$} \\
\hline & & $1 \mathrm{~m} / \mathrm{s}$ & $2 \mathrm{~m} / \mathrm{s}$ & $3 \mathrm{~m} / \mathrm{s}$ & $4 \mathrm{~m} / \mathrm{s}$ & $5 \mathrm{~m} / \mathrm{s}$ & $6 \mathrm{~m} / \mathrm{s}$ & \\
\hline \multirow{3}{*}{ High yield } & Erosion rate $(\mathrm{mm} / \mathrm{h})$ & 0 & 0 & 0.6000 & 12.00 & 6.00 & - & \multirow{3}{*}{12.00} \\
\hline & Avg. roughness (mm) & 0.09750 & 0.1036 & 0.1044 & 0.6458 & 0.6767 & - & \\
\hline & Shear stress $(\mathrm{Pa})$ & 3.000 & 11.50 & 25.90 & 40.00 & 115.6 & - & \\
\hline \multirow{3}{*}{ Low yield } & Erosion rate $(\mathrm{mm} / \mathrm{h})$ & 0 & 0 & 0 & 0 & 3.600 & 18.00 & \multirow{3}{*}{128.0} \\
\hline & Avg. roughness (mm) & 0.04620 & 0.6576 & 1.097 & 1.3317 & 1.518 & 1.840 & \\
\hline & Shear stress $(\mathrm{Pa})$ & 2.800 & 17.50 & 46.10 & 88.00 & 143.8 & 220.5 & \\
\hline
\end{tabular}




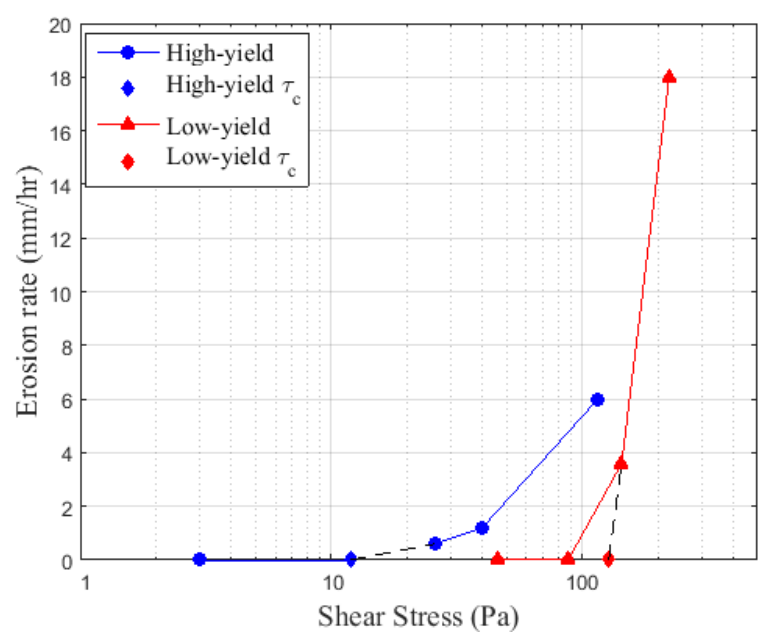

Figure 10. Soil erodibility vs. shear stress on the soil surface and resulting critical shear stress for the two samples. The blue circle markers indicate the soil from the highly productive area ("Highyield"; fig. 6). The red triangle markers are from the region of poor production ("Low-yield"; fig. 7) where claypan is found at the surface.

elevation. The high-performing region of the field shows no evidence of a clay layer down to a depth of $20 \mathrm{~m}$ in the soil profile. It appears this area of the field has a consistent deep layer of clayey sand topsoil (1-2 $\mathrm{m}$ deep), directly overlying the limestone parent material. The lack of an obvious clay pan indicates the spatially varying soil development processes within the field.

Areas of "scour" are common in crop production fields in the region. To date, however, the factors contributing to this variability have not been identified. The commonly held notion is that the clay layer is homogeneously present throughout the region. Our data show, however, that the clay layer is spatially variable. This heterogeneity of the clay layer is intriguing, especially given its location at the highest elevation region in this field. This may arise from greater weathering of the underlying limestone residuum due to loss of topsoil from these regions, as topsoil loss was much more extensive in the area with the clay layer.

A second important finding is the extent to which the spatial variability of the clay layer may contribute to different rates of erosion of the overlying material. The difference in critical shear stress between the productive topsoil and the unproductive clay layer indicate that the rate and extent of soil erosion from within a crop field will be highly variable based on subsoil composition. The impermeable clay layer is very resistant to erosion; however, it may enhance the rate of erosion of the topsoil due to its impervious nature. Presence of a perched watertable (Buckley, 2008) or processes of lateral flow (Jamison et al., 1968, Blanco-Canqui et al., 2002, Kitchen et al., 2003, 2005) may exacerbate erosion of the topsoil. The spatial variability of the subsoil continues to influence the surface runoff and internal soil drainage.

Current practices for modeling soil erosion rely on large scale parameters and are frequently inaccurate. To the author's knowledge, no measurements have been conducted to quantify the erodibility of claypan soils to date. Therefore, the measurements in this study can be used to determine the erodibility coefficient to better characterize claypan soil erosion potential. This study also highlighted the erosion variability in the field, despite the close proximity of the two study areas. Soil erosion tests showed the clay layer had a $967 \%$ increase in erosion resistance compared to the native topsoil. Again this supports the inaccuracy of large scale soil erosion models. Improving the variability with methodology presented here will improve large scale models.

The productive capacity of the field has been impaired due to topsoil loss and exposure of the clay layer (fig. 5; fig. 7). The ERT profile measured perpendicular to the two regions of variable yield indicated that the claypan does not slope away from the surface but rather diminishes across the field. The novel approach employed in this study showed that the clay layer that was believed to begin at 0.5 to $0.75 \mathrm{~m}$ below the surface and extend to bedrock is now approximately at the surface and only 1.3 to $1.5 \mathrm{~m}$ thick, at least in some regions of the field. More importantly, this clay layer is not homogeneously present throughout the field. By determining the true depth and thickness of the claypan, remediation practices can be implemented by future researchers in this highly localized zone. While plant cover and residues may protect the soil surface and reduce rates of soil loss from productive areas within the field, this may not be sufficient to control erosion in areas of exposed claypan. Soils high in clay content have low productivity levels (Kitchen et al., 2005; Sassenrath et al., 2015). More aggressive measures than only converting to no- or reduced-tillage may be required to ameliorate these areas. Methods such as use of animal manures, or cover crops may be required to improve the soil carbon content and microbial activity and improve soil productive capacity. Alternatively, removing the area from production for a period of time may allow improvement in soil health while reducing negative returns to the agronomic system due to poor yields.

In developing conservation practices to improve the productive capacity of agricultural fields, the spatial variability of soil characteristics, including the subsoil, must be taken into account. Current measurements of soil spatial variabilities are observing the integrated effects of more than 100 years of prior agricultural practices that have resulted in highly eroded areas of exposed claypan. Better understanding erodibility in claypan soils will allow us to implement better management practices (Mudgal et al., 2010), potentially on a spatially-specific pattern (Tomer et al., 2013).

\section{ACKNOWLEDGEMENTS}

The authors would like to thank Mr. Rich Falkenstien for collaborating in this research. The authors gratefully acknowledge the support of the Kansas State University Women in Engineering Program. The authors thank Lonnie Mengarelli, Garth Blackburn, and Adam Harris for their contribution to the field measurements. This manuscript is contribution number 17-133-J from the Kansas Agricultural Experiment Station. This work is supported by the USDA National Institute of Food and Agriculture, Hatch project 1003478. 


\section{REFERENCES}

AGI. (2001). Instruction manual for EarthImager 2D Ver. 2.2.0. Resistivity and IP Inversion Software. Austin, TX: Advanced Geosciences, Inc.

Alarcon, V. J., \& Sassenrath, G. F. (2015). Sensitivity of nutrient estimations to sediment wash-off using a hydrological model of Cherry Creek Watershed, Kansas, USA. In O. Gervasi, B. Murgante, S. Misra, M. L. Gavrilova, A. M. Rocha, C. Torre,... B. O. Apduhan (Eds.), Proc. 15th Int. Conf. ICCSA. Part III, LNCS 9157 (pp. 457-467). https://doi.org/10.1007/978-3-31921470-2 33

Alarcon, V. J., \& Sassenrath, G. F. (in press.). Water quality assessment in the Cherry Creek Watershed: Patterns of nutrient runoff in an agricultural watershed. JSWC.

Alberts, E. E., Nearing, M. A., Weltz, M. A., Risse, F. B., Pierson, F. B., Zhang, X. C.,... Simanton, J. R. (1995). Soil component. In D. C. Flanagan, \& M. S. Nearing (Eds.), USDA - Water erosion prediction project: Hillslope profile and watershed model documentation, 71 - 7.47. NSERL Report No. 10. Washington, DC: USDA, Agricultural Research Service, National Soil Erosion Research Laboratory.

Allred, B. J., Ehsani, M. R., \& Saraswat, D. (2006). Comparison of electromagnetic induction, capacitively-coupled resistivity, and galvanic contact resistivity methods for soil electrical conductivity measurement. Appl. Eng. Agric., 22(2), 215-230. https://doi.org/10.13031/2013.20283

Arjwech, R., Everett, M. E., Briaud, J.-L., Hurlebaus, S., MedinaCetina, Z., Tucker, S., \& Yousefpour, N. (2013). Electrical resistivity imaging of unknown bridge foundations. Near Surf. Geophys., 11(6), 591-598. https://doi.org/10.3997/18730604.2013023

ASTM. (2007). D422-63: Standard test method for particle-size analysis of soils. West Conshohocken, PA: ASTM Int.

ASTM. (2010). D4318-10: Standard test methods for liquid limit, plastic limit, and plasticity index of soils. West Conshohocken, PA: ASTM Int.

Bernhardt, M., Briaud, J.-L., Kim, D., Leclair, M., Storesund, R., Lim, S.-G.,... Rogers, J. D. (2011). Mississippi river levee failures: June 2008 flood. Int. J. Geoengineering Case Histories, 2(3), 127-162.

Bernstone, C., Dahlin, T., Ohlsson, T., \& Hogland, H. (2000). DC Resistivity mapping of internal landfill structures: Two preexcavation surveys. Environ. Geol., 39(3-4), 360-371. https://doi.org/10.1007/s002540050015

Binley, A., \& Kemna, A. (2005). DC Resistivity and induced polarization methods. In Y. Rubin, \& S. S. Hubbard (Eds.), Hydrogeophysics (Vol. 50, pp. 129-156). Dordrecht, The Netherlands: Springer. https://doi.org/10.1007/1-4020-3102-5_5

Blanco-Canqui, H., Gantzer, C. J., Anderson, S. H., Alberts, E. E., \& Ghidey, F. (2002). Saturated hydraulic conductivity and its impact on simulated runoff for claypan soils. SSSAJ, 66(5), 1596-1602. https://doi.org/10.2136/sssaj2002.1596

Briaud, J.-L. (2006). Bridge scour. Geotech. News, 24(3).

Briaud, J.-L., Ting Francis, C. K., Chen, H. C., Gudavalli, R., Perugu, S., \& Wei, G. (1999). SRICOS: Prediction of scour rate in cohesive soils at bridge piers. J. Geotech. Geoenviron. Eng., 125(4), 237-246. https://doi.org/10.1061/(ASCE)10900241(1999)125:4(237)

Buchleiter, G. W., \& Farahani, H. (2002). Comparison of electrical conductivity measurements from two different sensing technologies. ASAE Paper No. 021056. St. Joseph, MI: ASAE.

Buckley, M. E. (2008). Effect of tillage on the hydrology of claypan soils in Kansas. PhD diss. Manhattan, KS: Kansas State University, Department of Agronomy. Retrieved from https://krex.kstate.edu/dspace/handle/2097/943?show=full
Chandra, S., Dewandel, B., Dutta, S., \& Ahmed, S. (2010). Geophysical model of geological discontinuities in a granitic aquifer: Analyzing small scale variability of electrical resistivity for groundwater occurrences. J. Appl. Geophys., 71(4), 137-148. http://dx.doi.org/10.1016/j.jappgeo.2010.06.003

Constable, S. C., Parker, R., \& Constable, C. (1987). Occam's inversion: A practical algorithm for generating smooth models from electromagnetic sounding data. Geophys., 52(3), 289-300. https://doi.org/10.1190/1.1442303

Corwin, D. L., \& Lesch, S. M. (2005). Apparent soil electrical conductivity measurements in agriculture. Comput. Electron. Agric., 46(1), 11-43. http://dx.doi.org/10.1016/j.compag.2004.10.005

Daily, W., Ramirez, A., Binley, A., \& LaBrecque, D. (2005). Electrical resistance tomography: Theory and practice. In D. K. Butler (Ed.), Near-surface geophysics (13th ed., pp. 525-550). Tulsa, OK: Soc. Exploration Geophysicists. https://doi.org/10.1190/1.9781560801719.ch17

Doolittle, J. A., \& Brevik, E. C. (2014). The use of electromagnetic induction techniques in soils studies. Geoderma, 223-225, 3345. https://doi.org/10.1016/j.geoderma.2014.01.027

Doolittle, J. A., Sudduth, K. A., Kitchen, N. R., \& Indorante, S. J. (1994). Estimating depths to claypans using electromagnetic induction methods. $J S W C, 49(6), 572-575$. Retrieved from http://www.jswconline.org/content/49/6/572.abstract

Doolittle, J., Petersen, M., \& Wheeler, T. (2001). Comparison of two electromagnetic induction tools in salinity appraisals. JSWC, $56(3), 257-262$.

Doolittle, J. A., Indorante, S. J., Potter, D. K., Hefner, S. G., \& McCauley, W. M. (2002). Comparing three geophysical tools for locating sand blows in alluvial soils of southeast Missouri. JSWC, 57(3), 175-182.

Edwards, L. S. (1977). A modified pseudosection for resistivity and IP. Geophys., 42(5), 1020-1036. https://doi.org/10.1190/1.1440762

Everett, M. E. (2013). Near-surface applied geophysics. New York, NY: Cambridge University Press. https://doi.org/10.1017/CBO9781139088435

Flanagan, D. C., \& Nearing, M. A. (1995). USDA-Water Erosion Prediction Project: Hillslope profile and watershed model documentation. NSERL Report No. 10. Washington, DC: USDA, Agricultural Research Service, National Soil Erosion Research Laboratory.

Fleming, K. L., Heermann, D. F., \& Westfall, D. G. (2004). Evaluating soil color with farmer input and apparent soil electrical conductivity for management zone delineation. Agron. J., 96(6), 1581-1587. https://doi.org/10.2134/agronj2004.1581

Friedman, S. P. (2005). Soil properties influencing apparent electrical conductivity: A review. Comput. Electron. Agric., 46(1), 45-70. http://dx.doi.org/10.1016/j.compag.2004.11.001

Gadelmawla, E. S., Koura, M. M., Maksoud, T. M., Elewa, I. M., \& Soliman, H. H. (2002). Roughness parameters. J. Mater. Process. Technol., 123(1), 133-145. http://dx.doi.org/10.1016/S0924-0136(02)00060-2

Gaffney, C. (2008). Detecting trends in the prediction of the buried past: A review of geophysical techniques in archaeology. Archaeometry, 50(2), 313-336. https://doi.org/10.1111/j.14754754.2008.00388.x

Gantzer, C. J., Anderson, S. H., Thompson, A. L., \& Brown, J. R. (1991). Evaluation of soil loss after 100 years of soil and crop management. Agron. J., 83(1), 74-77. https://doi.org/10.2134/agronj1991.00021962008300010018x

Gebbers, R., Lück, E., Dabas, M., \& Domsch, H. (2009). Comparison of instruments for geoelectrical soil mapping at the field scale. Near Surf. Geophys., 7(3), 179-190. https://doi.org/10.3997/1873-0604.2009011 
Geng, R., Zhang, G.-H., Li, Z.-W., \& Wang, H. (2015). Spatial variation in soil resistance to flowing water erosion along a regional transect in the Loess Plateau. Earth Surf. Process. Landforms, 40(15), 2049-2058. https://doi.org/10.1002/esp.3779

Gessler, P. E., Moore, I. D., McKenzie, N. J., \& Ryan, P. J. (1995). Soil-landscape modelling and spatial prediction of soil attributes. Int. J. Geogr. Information Syst., 9(4), 421-432. https://doi.org/10.1080/02693799508902047

Grabowski, R. C., Droppo, I. G., \& Wharton, G. (2011). Erodibility of cohesive sediment: The importance of sediment properties. Earth-Sci. Rev., 105(3-4), 101-120. http://dx.doi.org/10.1016/j.earscirev.2011.01.008

Grand Lake O' the Cherokees Watershed Alliance Foundation. (2008). Grand Lake watershed plan: For improving water quality throughout the Grand Lake watershed. Draft. Retrieved from http://www.ok.gov/conservation/documents/Grand_Lake_\%20 WBP DRAFT.pdf

Griffiths, D. H., \& Barker, R. D. (1993). Two-dimensional resistivity imaging and modelling in areas of complex geology. J. Appl. Geophys., 29(3-4), 211-226. http://dx.doi.org/10.1016/0926-9851(93)90005-J

Groves, P., Cascante, G., Dundas, D., \& Chatterji, P. K. (2011). Use of geophysical methods for soil profile evaluation. Canadian Geotech. J., 48(9), 1364-1377. https://doi.org/10.1139/t11-044

Gupta, G., Patil, J. D., Maiti, S., Erram, V. C., Pawar, N. J., Mahajan, S. H., \& Suryawanshi, R. A. (2015). Electrical resistivity imaging for aquifer mapping over Chikotra basin, Kolhapur District, Maharashtra. Environ. Earth Sci., 73(12), 8125-8143. https://doi.org/10.1007/s12665-014-3971-5

Hanson, G. J. (1990). Surface erodibility of earthen channels at high stresses part II-developing an in situ testing device. Trans. ASAE, 33(1), 132-137. https://doi.org/10.13031/2013.31306

Hanson, G. J., Cook, K. R., \& Simon, A. (1999). Determining erosion resistance of cohesive materials. Proc. ASCE Int. Water Resources Engineering Conf. Reston, VA: ASCE.

Hiltunen, D., \& Roth, M. (2003). Investigation of bridge foundation sites in Karst Terrane via multi-electrode electrical resistivity. Proc. 3rd Int. Conf. on Applied Geophysics. Washington, DC: FHWA.

Ito, A. (2007). Simulated impacts of climate and land-cover change on soil erosion and implication for the carbon cycle, 1901 to 2100. Geophys. Res. Lett., 34(9), L09403. https://doi.org/10.1029/2007GL029342

Jamison, V. C., Smith, D. D., \& Thornton, J. F. (1968). Soil and water research on a claypan soil. USDA Tech. Bull. 1379. Washington, DC: U.S. Government Printing Office.

Jiang, P., Anderson, S. H., Kitchen, N. R., Sadler, E. J., \& Sudduth, K. A. (2007). Landscape and conservation management effects on hydraulic properties of a claypan-soil toposequence. SSSAJ, 71(3), 803-811. https://doi.org/10.2136/sssaj2006.0236

Jung, W. K., Kitchen, N. R., Sudduth, K. A., \& Anderson, S. H. (2006). Spatial characteristics of claypan soil properties in an agricultural field. SSSAJ, 70(4), 1387-1397. https://doi.org/10.2136/sssaj2005.0273

Kachanoski, R. G., van Wesenbeeck, I. J., \& Gregorich, E. G. (1988). Estimating spatial variations of soil water content using noncontacting electromagnetic inductive methods. Can. J. Soil Sci., 68(4), 715-722. https://doi.org/10.4141/cjss88-069

Kansas Data Access and Support. (2016). Retrieved from http://www.kansasgis.org/catalog/index.cfm

Kansas Mesonet. (2016). Historical weather. Kansas State University. Retrieved from http://mesonet.kstate.edu/weather/historical/

Kansas Water Office. (2016). John Redmond dredging initiative. Retrieved from http://www.kwo.org/projects/JohnRedmondDredging.html
Kauffman, G. J. (2002). What if... the United States of America were based on watersheds? Water Policy, 4(1), 57-68. http://dx.doi.org/10.1016/S1366-7017(02)00019-3

Kitchen, N. R., Sudduth, K. A., \& Drummond, S. T. (1999). Soil electrical conductivity as a crop productivity measure for claypan soils. J. Prod. Agric., 12(4), 607-617. https://doi.org/10.2134/jpa1999.0607

Kitchen, N. R., Drummond, S. T., Lund, E. D., Sudduth, K. A., \& Buchleiter, G. W. (2003). Soil electrical conductivity and topography related to yield for three contrasting soil-crop systems. Agron. J., 95(3), 483-495. https://doi.org/10.2134/agronj2003.4830

Kitchen, N. R., Sudduth, K. A., Myers, D. B., Drummond, S. T., \& Hong, S. Y. (2005). Delineating productivity zones on claypan soil fields using apparent soil electrical conductivity. Comput. Electron. Agric., 46(1), 285-308. http://dx.doi.org/10.1016/j.compag.2004.11.012

KSU. (2016). Crop production support. Kansas State University. Manhattan: Kansas State University Agricultural Experiment Station and Cooperative Extension Service. Retrieved from http://www.agronomy.k-state.edu/extension/cropproduction/index.html

Lal, R. (2003). Soil erosion and the global carbon budget. Environ. Int., 29(4), 437-450. http://dx.doi.org/10.1016/S01604120(02)00192-7

Lerch, R. N., Kitchen, N. R., Kremer, R. J., Donald, W. W., Alberts, E. E., Sadler, E. J.,... Ghidey, F. (2005). Development of a conservation-oriented precision agriculture system: Water and soil quality assessment. $J S W C, 60(6), 411-421$.

Lesparre, N., Boyle, A., Grychtol, B., Cabrera, J., Marteau, J., \& Adler, A. (2016). Electrical resistivity imaging in transmission between surface and underground tunnel for fault characterization. J. Appl. Geophys., 128, 163-178. http://dx.doi.org/10.1016/j.jappgeo.2016.03.004

Loke, M. H., \& Barker, R. D. (1996). Rapid least-squares inversion of apparent resistivity pseudosections by a quasi-Newton method. Geophys. Prospect., 44(1), 131-152. https://doi.org/10.1111/j.1365-2478.1996.tb00142.x

Lund, E. D., \& Christy, C. D. (1998). Using electrical conductivity to provide answers for precision farming. Proc. 1st Int. Conf. on Geospatial Information in Agriculture and Forestry.

Lund, E. D., Christy, C. D., \& Drummond, P. E. (1999). Practical applications of soil electrical conductivity mapping. In J. V. Stafford (Ed.), Proc. 2nd European Conf. on Precision Agriculture (pp. 771-779). Sheffield, U.K.: Sheffield Academic Press.

Meads, L. N., Bentley, L. R., \& Mendoza, C. A. (2003). Application of electrical resistivity imaging to the development of a geologic model for a proposed Edmonton landfill site. Canadian Geotech. J., 40(3), 551-558. https://doi.org/10.1139/t03-017

Molin, J. P., \& Faulin, G. D. (2013). Spatial and temporal variability of soil electrical conductivity related to soil moisture. Scientia Agricola, 70(1), 1-5.

Momm, H. G., Bingner, R. L., Wells, R. R., Rigby, J. R., \& Dabney, S. M. (2013). Effect of topographic characteristics on compound topographic index for identification of gully channel initiation locations. Trans. ASABE, 56(2), 523-537. https://doi.org/10.13031/2013.42673

Moody, L. F. (1944). Friction factors for pipe flow. Trans. ASABE, 66(8), 671-684.

Moore, I. D., Grayson, R. B., \& Ladson, A. R. (1991). Digital terrain modelling: A review of hydrological, geomorphological, and biological applications. Hydrol. Process., 5(1), 3-30. https://doi.org/10.1002/hyp.3360050103 
Mudgal, A., Anderson, S. H., Baffaut, C., Kitchen, N. R., \& Sadler, E. J. (2010). Effects of long-term soil and crop management on soil hydraulic properties for claypan soils. JSWC, 65(6), 393403. https://doi.org/10.2489/jswc.65.6.393

Mueller, T. G., Zourarakis, D., Sassenrath, G. F., Mijatovic, B., Dillon, C., Gianello, E.,... Faleiros, G. D. (2015). Remote sensing, soil surveys, and topographic analysis for conservation planning. In T. G. Mueller, \& G. F. Sassenrath (Eds.), GIS applications in agriculture. Conservation planning (Vol. 4, pp. 11-35). Abingdon, U.K.: Taylor and Francis.

Munson, B. R., Young, D. F., \& Okiishi, T. H. (1990). Fundamentals of fluid mechanics (Vol. 3). New York, NY: Wiley.

Napoli, M., Cecchi, S., Orlandini, S., Mugnai, G., \& Zanchi, C. A. (2016). Simulation of field-measured soil loss in Mediterranean hilly areas (Chianti, Italy) with RUSLE. CATENA, 145, 246256. http://dx.doi.org/10.1016/j.catena.2016.06.018

NRCS. (2016). Web Soil Survey. Retrieved from http://websoilsurvey.sc.egov.usda.gov/App/HomePage.htm

Papadopoulos, N., Sarris, A., Yi, M.-J., \& Kim, J.-H. (2009). Urban archaeological investigations using surface $3 \mathrm{D}$ ground penetrating radar and electrical resistivity tomography methods. Explor. Geophys., 40(1), 56-68. https://doi.org/10.1071/EG08107

Partheniades, E. (1965). Erosion and deposition of cohesive soils. $J$. Hydraulic Division of ASCE, 91(1), 105-139.

Perovic, V., Zivotic, L., Kadovic, R., Dordevic, A., Jaramaz, D., Mrvic, V., \& Todorovic, M. (2013). Spatial modelling of soil erosion potential in a mountainous watershed of South-eastern Serbia. Environ. Earth Sci., 68(1), 115-128. https://doi.org/10.1007/s12665-012-1720-1

Renard, K. G., Foster, G. F., Weesies, G. A., \& Porter, J. P. (1991). RUSLE-Revised universal soil loss equation. JSWC, 46(1), 3033.

Rhoades, J. D., Manteghi, N. A., Shouse, P. J., \& Alves, W. J. (1989). Soil electrical conductivity and soil salinity: New formulations and calibrations. SSSAJ, 53(2), 433-439. https://doi.org/10.2136/sssaj1989.03615995005300020020x

Sassenrath, G. F., Lin, X., \& Shoup, D. E. (2015). Identification of yield-limiting factors in southeast Kansas cropping systems. Kansas Agric. Experiment Station Res. Reports, 1(4), Art. 5.

Sharma, P. V. (1997). Environmental and engineering geophysics. Cambridge, U.K.: Cambridge University Press. https://doi.org/10.1017/CBO9781139171168
Snapp, M., Tucker-Kulesza, S., \& Koehn, W. (2017). Electrical resisitivity of mechancially stablized earth wall backfill. J. Appl. Geophys., 141, 98-106. http://dx.doi.org/10.1016/j.jappgeo.2017.04.011

Sudduth, K. A., Drummond, S. T., \& Kitchen, N. R. (2001). Accuracy issues in electromagnetic induction sensing of soil electrical conductivity for precision agriculture. Comput. Electron. Agric., 31(3), 239-264. http://dx.doi.org/10.1016/S0168-1699(00)00185-X

Sudduth, K. A., Kitchen, N. R., Bollero, G. A., Bullock, D. G., \& Wiebold, W. J. (2003). Comparison of electromagnetic induction and direct sensing of soil electrical conductivity. Agron. J., 95(3), 472-482. https://doi.org/10.2134/agronj2003.4720

Tarboton, D. (2015). TauDEM - Terrain analysis using digital elevation models. Logan, Utah: Utah State University. Retrieved from http://hydrology.usu.edu/taudem

Tomer, M. D., Porter, S. A., James, D. E., Boomer, K. M. B., Kostel, J. A., \& McLellan, E. (2013). Combining precision conservation technologies into a flexible framework to facilitate agricultural watershed planning. $J S W C, 68(5), 113 \mathrm{~A}-120 \mathrm{~A}$. https://doi.org/10.2489/jswc.68.5.113A

Tran, T., Tucker-Kulesza, S., \& Bernhardt, M. (in press). Determining surface roughness in erosion testing using digital photogrammetry. ASTM Geotechnical Testing J., 46(6). 1-12. https://doi.org/10.1520/GTJ20160277

Tucker, S. E., Briaud, J.-L., Hurlebaus, S., Everett Mark, E., \& Arjwech, R. (2015). Electrical resistivity and induced polarization imaging for unknown bridge foundations. $J$. Geotech. Geoenviron. Eng., 141(5). https://doi.org/10.1061/(ASCE)GT.1943-5606.0001268

USGS. (2015). National agricultural imagery program. Reston, VA: USGS. Retrieved from http://nationalmap.gov/

Wang, B., Zheng, F., Romkens, M. J., \& Darboux, F. (2013). Soil erodibility for water erosion: A perspective and Chinese experiences. Geomorphol., 187, 1-10. http://dx.doi.org/10.1016/j.geomorph.2013.01.018

Whitman, D., \& Yeboah-Forson, A. (2015). Electrical resistivity and porosity structure of the upper Biscayne Aquifer in MiamiDade County, Florida. J. Hydrol., 531, 781-791. http://dx.doi.org/10.1016/j.jhydrol.2015.10.049

Wischmeier, W. H., \& Smith, D. D. (1978). Predicting rainfall erosion losses: A guide to conservation planning. USDA Agric. Handbook 537. Washington, DC: U.S. Government Printing Office. 